\title{
Rasa Malu dan Presentasi Diri Remaja di Media Sosial
}

\author{
Herdyani Kusumasari dan Diana Savitri Hidayati ${ }^{1}$ \\ Fakultas Psikologi Universitas Muhammadiyah Malang
}

\begin{abstract}
An individual will perform self-impression to be accepted by society and can establish a social relationship. Someone do the self presentation so they can be accepted by the environment. However, there are some people which have obstacle to do their self presentation to make a social relationship. We can called that condition with shyness. Social media can be well accepted a mediator for shy person to presented their self. The purpose of this research is to find out the correlation between shynees with self presentation on adolosence in social media. This research has done to 96 sample of 13 - 16 years old active user of social media like Facebook, Twitter, Path, Instagram, Blog, and Youtube. The result with Pearson Product Moment test says the coeficient correlation ( $r$ ) between two variables is 0,281. That is shows that between the two variables have a positive correlation with the signification level is $0,006(p<0,05)$ which says that the two variables have a significant correlation.
\end{abstract}

Keywords: Shyness, Self-presentation, Social Media, Adolosence.

\begin{abstract}
Abstrak: Individu akan melakukan pengelolaan kesan agar dapat diterima oleh masyarakat dan dapat menjalin sebuah hubungan sosial. Presentasi diri dilakukan agar individu dapat diterima dengan baik oleh lingkungan sekitarnya. Namun, beberapa orang akan mengalami suatu hambatan dalam melakukan presentasi dirinya secara langsung untuk melakukan suatu hubungan sosial. Kondisi tersebut dapat dikatakan sebagai rasa malu (shyness). Media sosial merupakan salah satu perantara bagi orang pemalu untuk melakukan presentasi dirinya. Tujuan dari penelitian ini adalah untuk mengetahui hubungan antara rasa malu dengan presentasi diri remaja melalui media sosial. Penelitian ini dilakukan pada 96 orang remaja berusia 13 - 16 tahun yang aktif di media sosial yaitu Facebook, Twitter, Path, Instagram, Blog, dan Youtube. Hasil yang diperoleh dengan uji Pearson Product Moment menunjukkan koefisien korelasi (r) antara kedua variabel sebesar 0,281 dengan taraf signifikasinya adalah $0,006(\mathrm{p}<0,05)$, hal tersebut menunjukkan bahwa antara kedua variabel memiliki hubungan positif yang signifikan.
\end{abstract}

Kata Kunci: Rasa Malu, Presentasi Diri, Media Sosial, Remaja.

Media sosial yang saat ini mulai berkembang di kalangan anak muda seperti Facebook, Twitter, Instagram, Blogger, dan sebagainya dapat dikatakan sebagai fasilitas untuk melakukan sebuah hubungan sosial di dunia maya. Kebanyakan pengguna akun media sosial melakukan pencarian teman sebanyak-banyaknya melalui akun tersebut agar dianggap populer. Padahal tidak semua akun yang meminta untuk menjadi teman di media sosial adalah orang yang benar-benar dikenal.

Media sosial seakan menjadi dunia baru bagi pengguna internet untuk menunjukkan dirinya kepada orang lain. Apalagi saat ini banyak tersedia alat komunikasi (gadget) dengan harga terjangkau yang memudahkan penggunanya untuk melakukan akses media

\footnotetext{
Korespondensi tentang artikel ini dapat dialamatkan kepada Diana Savitri Hidayati melalui e-mail:dhi2savitri@gmai.com
} 
sosial. Hal tersebut menyebabkan akun media sosial dapat dimiliki oleh setiap kalangan. Tidak perlu dipungkiri jika saat ini orang lebih banyak terlihat sibuk dengan gadget mereka daripada dengan situasi di sekitarnya. Update status, mengunggah foto maupun video, mencurahkan perasaan, dan interaksi pribadi lainnya dapat dengan mudah dilakukan di media sosial. Nurudin (2012) juga menganggap bahwa media sosial seperti Facebook banyak digunakan untuk memanjatkan doa, seakan media sosial adalah Tuhan baru di kalangan masyarakat saat ini dengan berbagai macam bentuk komunikasi serba digital.

Maraknya penggunaan media sosial tersebut membuat presentasi diri di media sosial menjadi kegiatan yang sangat penting. Presentasi diri (self presentation) biasanya dilakukan seseorang untuk memulai sebuah hubungan dengan orang lain dengan cara pengungkapan diri. Presentasi diri dilakukan agar individu dapat diterima dengan baik oleh lingkungan sekitarnya. Agar dapat diterima oleh masyarakat, individu akan melakukan pengelolaan kesan, yaitu proses dimana individu melakukan seleksi dan mengontrol perilaku mereka sesuai dengan situasi dimana perilaku itu dihadirkan serta memproyeksikan pada orang lain suatu image yang diinginkannya (Dayakisni \& Hudaniah, 2009). Oleh karena itu, media sosial dapat membantu seseorang untuk membuat gambaran diri yang diinginkan sebebasbebasnya dengan tujuan agar dapat diterima oleh orang lain disekitarnya.

Pentingnya presentasi diri di media sosial membuat seseorang akan melakukan apapun untuk menarik perhatian orang lain. Seperti contoh kasus seorang wanita asal Los Angeles yang terobsesi dengan media sosial rela melakukan operasi plastik berkali-kali agar terlihat menarik saat melakukan foto selfie yang diunggah pada akun media sosialnya (Nigrum, 2014). Lain halnya dengan wanita asal Tiongkok yang mengunggah foto cantik yang mencerminkan dirinya di media sosial demi mendapatkan pria idaman. Namun ternyata setelah bertemu secara langsung, sang pria sangat kecewa dan marah karena gambaran diri wanita tersebut tidak sesuai dengan foto yang ditampilkan di media sosial (Alia, 2015).

Berdasarkan contoh kasus diatas, seseorang perlu memikirkan kembali dampak baik maupun buruk yang terjadi setelah melakukan presentasi di media sosial terhadap dirinya. Dampak dari presentasi diri melalui media sosial tersebut bisa menjadi positif maupun negatif tergantung dari cara seseorang tersebut mempresentasikan dirinya. Dampak positif dalam melakukan presentasi diri di media sosial antara lain dapat menjalin hubungan dengan keluarga maupun teman yang sudah lama tidak bertemu, menambah teman, meningkatkan kesempatan untuk belajar, dan memudahkan untuk berbagi informasi terbaru (O'Keeffe \& Pearson, 2011). Sedangkan dampak negatifnya antara lain berkurangnya privasi, mengurangi kemampuan bersosialisasi di dunia nyata, cybercrime bahkan pornografi.

Kecenderungan dalam penggunaan media sosial merupakan adanya perasaan individual dan dorongan untuk diakui dan promosi diri (Albarran, 2013). Tidak hanya orang dewasa, pengguna internet saat ini juga telah didominasi oleh anak remaja. Hasil penelitian Pew Internet \& American Life Project menunjukkan pada tahun 2007, sebanyak $93 \%$ remaja pengguna internet usia 12 - 17 tahun memberikan perlakuan pada aktivitas di internet sebagai tempat untuk interaksi sosial dimana remaja dapat berbagi hasil kreativitasnya, menceritakan pengalaman, dan berinteraksi dengan orang lain (Lenhart dkk, 2007). Livingstone (dalam Albarran, 2013) juga mengungkapkan bahwa remaja pada umumnya menggunakan media sosial untuk mendapatkan banyak teman, 
adanya sedikit privasi, dan pesona narsistik dengan menunjukkan dirinya.

Kementrian Kominfo yang dibantu oleh UNICEF melakukan sebuah penelitian mengenai aktivitas online pada anak-anak dan remaja usia 10-19 tahun. Penelitian tersebut menunjukkan bahwa dari 98 persen anakanak dan remaja yang disurvei, 79,5 persen diantaranya adalah pengguna internet (Broto, 2014). Menurut Broto (2014), tiga hal yang mendorong atau memotivasi anak-anak dan remaja melakukan akses internet adalah untuk mencari informasi, menghubungkan dengan teman-temannya (baik yang sudah lama mapun baru), dan sebagai hiburan. Media sosial merupakan salah satu akses bagi setiap orang agar terhubung dengan temantemannya di dunia maya.

Menurut Papalia, Olds, dan Feldman (2009) masa remaja dimulai pada usia 12 atau 13 tahun dan berakhir pada awal dua puluhan tahun. Hurlock (1980) mengungkapkan bahwa remaja diawali pada usia 13 - 16 tahun. Individu akan mengalami tahap pencarian identitas diri saat mulai memasuki usia tersebut. Hal itu sesuai dengan tahap perkembangan Erikson yang kelima (Santrock, 2003). Saat individu memasuki usia ini maka perilaku yang muncul merupakan pengaruh dari pergaulan lingkungan, terutama dengan kelompok teman sebaya.

Pada tahap perkembangan remaja tersebut, individu membutuhkan pergaulan dengan teman sebaya lebih banyak daripada dengan orangtua. Menurut Hurlock (1997), hal tersebut dikarenakan remaja membutuhkan seseorang yang dapat dipercaya, dapat diajak bicara, dan dapat diandalkan. Oleh karena itu, remaja lebih banyak meluangkan waktu dengan teman sebayanya karena memiliki minat dan nilainilai yang sama. Minat individu pada tahap remaja tidak lagi pada teman yang sejenis, namun bertambah lebih besar pada lawan jenisnya. Penggunaan sosial media di kalangan remaja merupakan salah satu bentuk pengaruh kelompok teman sebaya terhadap individu agar turut aktif dalam pembuatan akun di dunia maya. Individu akan menampilkan sisi terbaik mereka melalui akun tersebut untuk memperoleh kesan baik dari pengguna media sosial lainnya. Penampilan kesan dapat dilakukan melalui update status, profil, komentar kepada "teman" lain, dan sebagainya.

Sebuah penelitian dilakukan oleh Mitja D. Back yang merupakan pengajar psikologi di Johannes Guttenberg-University of Mainz mengenai profil seseorang di media sosial (dalam Fahmi, 2011). Hasil tersebut menunjukkan bahwa seseorang menggunakan profil di media sosial bukan untuk menampilkan identitas yang ideal, namun untuk menampilkan kepribadian mereka yang sebenarnya yang mungkin dapat meningkatkan ketenaran. Jadi bagaimanapun seseorang membuat profil sebaik apapun, hal tersebut tetap mempresentasikan kepribadian individu yang sebenarnya.

Penelitian Wong (2012) yang menguji mengenai presentasi diri dan pencarian dukungan sosial mahasiswa melalui Facebook. Hasil penelitian menunjukkan bahwa mahasiswa melakukan pencarian dukungan sebagai bentuk interaksi dengan teman-temannya daripada melakukan selfupdate. Self-update merupakan bagian dari presentasi diri yang dilakukan di media sosial. Selain itu, mahasiswa juga membentuk perilaku serta mempresentasikan diri mereka terhadap kesan yang diharapkannya. Penggunaan Facebook juga dilakukan untuk mencari dan menerima dukungan sosial saat dibutuhkan.

Individu yang cenderung memiliki determinasi diri rendah akan lebih sering menggunakan presentasi diri (Lewis \& Neigbors, 2005). Determinasi diri masingmasing individu terdiri dari tiga tujuan yang 
berbeda yaitu otonomi, kontrol, dan impersonal. Individu yang mengontrol dan tidak menunjuk orang tertentu (impersonal) sebagai tujuannya, menunjukkan hasil yang lebih tinggi dalam melakukan strategi presentasi diri. Sedangkan individu yang tujuannya bersifat otonomi menunjukkan lebih sedikit dalam penggunaan strategi presentasi diri. Penelitian dari Ong, dkk (2011) menjelaskan mengenai hubungan antara narsisme dan extrovert dengan presentasi diri remaja di Facebook. Hasil menunjukkan bahwa remaja narsistik maupun ekstrovert lebih menonjolkan sisi dari diri mereka secara umum, seperti rating foto profil maupun banyaknya update status.

Presentasi diri juga dilakukan saat seseorang melakukan kegiatan online pribadi, seperti untuk melakukan kencan online (online dating) sesuai dengan hasil penelitian oleh Gibbs, Ellison, dan Heino (2006). Penelitian tersebut menemukan bahwa terdapat empat dimensi keterbukaan diri (selfdisclosure) yang dirasa membuat sukses kegiatan kencan online yaitu kejujuran, kuantitas, tujuan, dan valensi. Namun dimensi kejujuran tersebut memiliki efek negatif. Lebih jauh lagi, pengalaman merupakan salah satu prediktor kesuksesan seseorang dalam melakukan online dating. Jadi, penelitian tersebut secara tidak langsung mengidentifikasi kesuksesan online dating dengan strategi yaitu berdasarkan pengalaman versus kesuksesan dengan presentasi diri.

Jensen dkk. (2010) melakukan penelitian mengenai pengaruh interaksi dalam melakukan presentasi diri. Pengaruh interaksi tersebut berupa motivasi kesan dan pola pikir seseorang saat melakukan presentasi diri dalam inventori kepribadian. Hasil penelitian menunjukkan bahwa motivasi kesan maupun pola pikir sangat berpengaruh signifikan terhadap presentasi diri. Subjek dengan tingkat motivasi kesan yang tinggi menunjukkan pola pikir yang kuat berpengaruh terhadap presentasi diri.

Berdasarkan hasil penelitian penelitian yang telah dilakukan seperti yang diuraikan sebelumnya menggambarkan pentingnya presentasi diri seseorang yang dilakukan individu di dunia maya. Presentasi diri yang dilakukan di dunia maya merupakan karakter yang dibentuk atau diinginkan seseorang agar dapat melakukan interaksi dengan teman-temannya maupun mencari perhatian lawan jenis untuk melakukan hubungan lebih lanjut. Lebih lanjut diungkapkan bahwa pengalaman seseorang yang sering berinteraksi di dunia maya mendapat lebih banyak respon dari orang lain, namun kejujuran memiliki dampak yang negatif. Jadi orang lain tidak dapat mengetahui bagaimana karakter seseorang tersebut yang sebenarnya.

Beberapa orang akan mengalami suatu hambatan dalam melakukan presentasi dirinya secara langsung untuk melakukan suatu hubungan sosial. Kondisi tersebut dapat dikatakan sebagai rasa malu (shyness), dengan pengertian menurut Lynn Henderson dan Philip Zimbardo adalah suatu keadaan dimana seseorang mengalami ketidaknyamanan atau adanya hambatan dalam suatu keadaan interpersonal (situasi yang melibatkan interakasi dengan orang lain), dan ketidaknyamanan tersebut memiliki pengaruh terhadap tujuan interpersonal maupun profesional (dalam Maltby dkk, 2007).

Rasa malu (shyness) yang dimiliki oleh orang dewasa maupun orangtuanya tidak berhubungan dengan kemampuan sosial yang dimiliki. Hal itu sesuai dengan hasil penelitian yang telah dilakukan oleh Arroyo, Nevarez, dkk (2012). Lebih lanjut dijelaskan bahwa kemampuan sosial yang dimiliki orang dewasa berhubungan signifikan dengan komunikasi keluarga yang dirasakan, namun tidak berhubungan dengan kemampuan sosial 
orangtua mereka. Hal tersebut dapat diprediksi bahwa orang dewasa dan orangtua yang memiliki rasa malu tinggi akan menunjukkan ketidakefektifan kemampuan sosialnya yang berhubungan dengan kurangnya persepsi positif dalam komunikasi keluarga.

Baker dan Oswald (2010) mengindikasikan hasil penelitian yang menunjukkan bahwa interaksi antara shyness dan pengguna Facebook, dimana individu yang memiliki rasa malu tinggi (saat dibandingkan dengan individu yang memiliki rasa malu rendah), memiliki hubungan yang kuat dalam penggunaan Facebook dan kualitas pertemanannya. Penggunaan Facebook tidak berhubungan dengan kesepian diantara individu yang memiliki tingkat rasa malu tinggi. Layanan jaringan sosial online kemungkinan merupakan tempat yang nyaman bagi individu yang pemalu untuk berinteraksi dengan orang lain.

Uraian latar belakang tersebut menunjukkan bahwa presentasi diri merupakan salah satu hal yang penting bagi seseorang untuk menjalin sebuah hubungan dengan orang lain. Hubungan yang dimaksud bisa berupa hubungan pertemanan, rekan bisnis, teman diskusi, maupun dalam pencarian pasangan hidup. Melalui media sosial individu memiliki ruang yang luas untuk menunjukkan atau mempresentasikan dirinya sesuai dengan apa yang diinginkan. Menurut Schlenker \& Leary (1982), ada dua kemungkinan seseorang memiliki rasa aman dalam lingkungan sosialnya yaitu saat seseorang tidak memiliki tujuan tertentu untuk memberikan kesan pada orang lain sehingga tidak terlalu memikirkan reaksi orang lain terhadap dirinya. Kemungkinan lainnya adalah seseorang berusaha untuk memberikan kesan tertentu pada orang lain dan percaya bahwa hal tersebut dapat dilakukannya. Dalam hal ini seorang pemalu memiliki rasa aman saat berinterkasi sosial di media sosial karena mereka lebih mampu memberikan kesan mengenai dirinya secara bebas tanpa menghadapi secara langsung reaksi dari orang lain.

Berdasarkan hasil penelitian yang telah diuraikan sebelumnya, individu dengan shyness tinggi lebih nyaman melakukan interaksi sosial melalui media sosial. Dapat dikatakan bahwa media sosial merupakan salah satu perantara bagi orang pemalu untuk melakukan presentasi dirinya yang sebenarnya. Menurut asumsi penulis, rasa malu memiliki hubungan terhadap presentasi diri yang dilakukan seseorang di dunia maya atau media sosial karena bentuk interaksi dengan orang lain tidak langsung namun cukup mendapat timbal balik.

Melalui penelitian ini dimunculkan sebuah rumusan masalah yaitu bagaimana hubungan antara shyness dengan presentasi diri remaja melalui media sosial. Sedangkan tujuan dari penelitian ini adalah untuk mengetahui hubungan antara shyness dengan presentasi diri remaja melalui media sosial. Manfaat yang didapatkan dari penelitian ini adalah untuk menambah bahan penelitian dalam bidang psikologi sosial mengenai hubungan yang terjadi antara rasa malu dengan presentasi diri seseorang melalui media sosial

\section{Presentasi Diri}

Menurut De Lamater dan Myers (2007) presentasi diri adalah usaha yang dilakukan individu, baik sadar maupun tidak sadar, untuk mengontrol diri sendiri sesuai dengan gambaran yang diinginkan dalam suatu interaksi sosial. Bentuk dari presentasi diri ada yang terjadi secara alami atau natural, namun juga ada beberapa yang dibuat-buat. Presentasi diri yang berhasil membutuhkan usaha untuk mengontrol bagaimana orang lain mendefinisikan situasi interaksi dan mengikutsertakan identitas yang disetujui.

Schlenker mengungkapkan bahwa 
presentasi diri merupakan bagian dari impression management yang merupakan suatu usaha untuk mengatur kesan yang orang lain tangkap mengenai kita baik yang disadari maupun tidak (dalam Sarwono \& Meinarno, 2012). Sehingga impression management dapat memprediksi presentasi diri yang akan tampak dalam suatu situasi sosial. Namun kegagalan identitas dapat terjadi karena ketidakefektifan presentasi diri. Konsekuensi yang harus dihadapi jika terjadi kegagalan antara lain (De Lamater \& Myers, 2007): (a) individu akan merasa malu jika identitas yang ditunjukkan tidak dipercaya; (b) pengulangan kegagalan yang tampak jelas dalam melakukan presentasi diri membuat orang lain mengubah identitas pelaku dengan tindakan yang disengaja; (c) muncul stigma cacat fisik, moral, dan sosial individu dan secara permanen merusak identitas mereka.

Menurut teori Goffman (dalam Dayakisni \& Hudaniah, 2009) terdapat enam macam strategi presentasi diri yang dilakukan seseorang, yaitu: (a) Ingratiation; yaitu bentuk startegi seseorang dengan mengambil muka / menjilat dengan pujian, pendengar yang baik, ramah, dan sebagainya agar tampak tulus di depan orang lain. (b) Intimidation; startegi ini dilakukan agar seseorang tampak menakutkan dan berbahaya. (c) Self-promotion; untuk menunjukkan pada orang lain bahwa dirinya kompeten atau ahli dalam bidang tertentu. (d) Exemplification; startegi ini dilakukan seseorang untuk memproyeksikan penghargaannya pada kejujuran dan moralitas, namun terkadang tidak tulus dalam melakukannya. (e) Supplification; seseorang menujukkan kelemahannya pada orang lain untuk mendapatkan pertolongan maupun simpati. (f) Self-handicapping; seseorang berpura-pura mendapat hambatan saat melakukan kegiatan saat merasa ego yang dimiliki terancam.

Baumeister (dalam Grietens, 1999) membagi motif presentasi diri ke dalam dua kategori yaitu memuaskan audience dan membangun diri (self-construction). Jika tujuan utamanya adalah memuaskan audience, individu tersebut berharap menerima kembali kebaikan berupa materi atau penghargaan dari sosialnya dengan menampilkan karakteristik dirinya yang dapat membuat orang lain akan mengapresiasi. Jika self-construction menjadi target utama, presentasi diri akan diartikan sebagai maksud dari pemenuhan diri sendiri. Presentasi diri ditujukan untuk menetapkan, memelihara, dan membersihkan sebuah gambaran individu dalam pikiran orang lain. Hal tersebut menjadi sesuatu yang perlu dipertimbangkan pada identitas sosial individu.

\section{Rasa Malu}

Definisi rasa malu (shyness) menurut Carducci \& Golant (2009) adalah adanya ketidaknyamanan dan hambatan perilaku yang terjadi jika terdapat kehadiran orang lain di dekatnya. Bentuk shyness dapat ditunjukkan dengan diam, perasaan malu, muka menjadi merah, gagap, dan cemas. Namun perilaku shyness juga dapat diobservasi langsung dengan ciri-cirinya yaitu menjadi lebih pendiam dan menghindari orang-orang maupun lingkungan sekitar yang memberikan stimulus. Lebih lanjut Carducci dan Golant menjelaskan bahwa biasanya orang-orang menghubungkan shyness dengan introvert, namun introvert tidak selalu pemalu. Terlihat cemas, kesadaran diri, dan pikiran untuk melawan yang biasanya terjadi pada pemalu tidak tampak pada introvert. Orang pemalu sangat menginginkan oranglain untuk memperhatikan dan menerima mereka, namun mereka tampaknya tidak memilki kemampuan pikiran, perasaan, dan sikap yang mampu membantu mereka menghadapi interaksi sosial.

Shyness bukan penyakit sosial seperti social phobia atau gangguan kecemasan 
sosial. Penyakit mental tersbut biasanya dirawat dengan pengobatan dan psikoterapi. Shyness tidak termasuk dalam Diagnostic and Statistical Manual of Mental Disorder IV (DSM IV) karena hal itu bukan penyakit mental, namun hanya fase normal dari kepribadian. Orang pemalu kebanyakan tidak mencoba untuk untuk menghindari orang lain namun lebih mencari mereka walaupun mengalami kesulitan dalam membuat suatu hubungan.

Menurut Dingman \& Bloom (2012) rasa malu terjadi saat seseorang tidak melakukan suatu perilaku yang menjadi kepentingan terbaik mereka sendiri karena merasa takut bahwa hasilnya akan negatif. Shyness dapat dideskripsikan juga sebagai rasa cemas atau canggung saat seseorang berada di suatu situasi baru atau didekati oleh orang lain yang tidak dikenal. Bentuk yang lebih kuat dari shyness adalah social anxiety atau social phobia dan bisa termasuk dalam salah satu gejala Asperger.

Maltby (2007) mengungkapkan bahwa reaksi shyness dapat terjadi pada beberapa atau semua tingkatan berikut: (a) kognisi, (b) afeksi, (c) fisik, dan (d) perilaku. Salah satu contoh gejala yang tampak pada masingmasing tingkatan seperti pada tingkat kognisinya yaitu takut terhadap evaluasi negatif dan terlihat bodoh di depan orang lain. Orang yang memiliki rasa malu akan berpikir bahwa dirinya lemah sedangkan orang lain memiliki power atau kuat. Pada tingkat afeksi gejala yang muncul antara lain perasaan malu, self-esteem rendah, cemas, depresi, dan sebagainya. Muka memerah, berkeringat, merasa pusing, gemetaran, dan jantung berdetak cepat merupakan gejala yang tampak jika dilihat dari fisiknya. orang pemalu juga akan melakukan perilaku yang tampak tidak nyaman jika melakukan interaksi dengan orang lain seperti berbicara sangat pelan, melakukan kesalahan dalam berbicara (bicara terlalu cepat atau tiba-tiba tidak bisa mengeluarkan kata-kata), dan lain sebagainya.

Terdapat dua jenis shyness yaitu situational (state) shyness dan dispositional (trait) shyness. Situational shyness melibatkan emosi dan kognisi yang merupakan pengalaman dari rasa malu itu sendiri. Tipe ini dapat terjadi sewaktu-waktu oleh siapapun, terutama pada suatu situasi sosial. Sedangkan dispositional shyness merupakan malu yang bersifat jangka panjang atau permanen walaupun dalam waktu maupun situasi yang berbeda. Russell, Cutrona, \& Jones (dalam Maltby dkk, 2007) mengungkapkan bahwa dispositional shyness dapat berkurang saat keadaan sekitar yang harus dihadapi berubah. Tipe ini merupakan ciri kepribadian yang muncul secara stabil sewaktu-waktu dan tergantung situasi yang dihadapi.

Melalui tinjauan teori yang telah dijelaskan di atas dapat diambil sebuah hipotesis bahwa terdapat hubungan positif antar variabel penelitian. Dapat dikatakan jika seorang remaja memiliki rasa malu yang tinggi, maka semakin tinggi pula presentasi diri yang dilakukannya di media sosial.

\section{METODE}

Penelitian ini menggunakan pendekatan kuantitatif. Azwar (2001) menjelaskan bahwa pendekatan kuantitatif merupakan pendekatan yang lebih menekankan analisisnya pada data numerikal atau angka kemudian dihitung dengan metode statistik. Rancangan penelitian menggunakan penelitian korelasional yaitu penelitian yang dilakukan untuk mengetahui hubungan antar variabel yang diteliti (Azwar, 2001). Terdapat dua variabel yang diteliti yaitu variabel bebas (independent) dan variabel terikat (dependent). Varibel bebas dalam penelitian ini adalah rasa malu dan variabel terikatnya adalah presentasi diri. 


\section{Partisipan}

Subjek penelitian yang digunakan adalah remaja dengan rentang usia antara 13 hingga 16 tahun. Selain itu subjek juga masih aktif dalam penggunaan media sosial, seperti Facebook, Twitter, Blog, Path, Youtube, dan Instagram. Kriteria aktif di media sosial yaitu subjek masih melakukan update status, tulisan, maupun foto dan memberikan komentar atau tanggapan pada akun lain setiap hari atau setidaknya minimal seminggu sekali. Subyek penelitian berjumlah 96 subjek, dimana subjek dengan jenis kelamin perempuan berjumlah 65 orang dan laki - laki berjumlah 31 orang. Teknik sampling yang digunakan adalah accidental sampling. Menurut Latipun (2011) accidental sampling merupakan sampel yang diambil karena faktor kebetulan yang dijumpai peneliti sesuai dengan kriteria penelitian.

\section{Teknik Pengumpulan Data}

Rasa malu adalah suatu keadaan dimana individu merasa gugup dan menghindari interaksi sosial dengan orang lain karena cemas mendapatkan evaluasi dari orang lain mengenai dirinya. Instrumen penelitian yang digunakan untuk mengukur rasa malu adalah adaptasi serta pengembangan Shyness Scale dari Buss and Cheek dengan model skala Likert. Aspek yang akan diungkap dalam skala rasa malu ini meliputi kognitif, afektif, fisik, dan perilakunya. Aspek-aspek tersebut berdasarkan teori yang diungkapkan oleh Maltby dkk (2007) mengenai reaksi rasa malu dalam tingkatan aspek tersebut. Validitas skala bergerak dari 0,326-0,671, sedangkan uji reliabilitas item menggunakan Cronbach's Alpha adalah 0,904.

Presentasi diri adalah upaya individu untuk berperilaku sesuai dengan penilaian orang lain terhadap dirinya sendiri agar dapat diterima dalam suatu hubungan dengan melakukan strategi-strategi tertentu. Instrumen penelitian tersebut mengenai presentasi diri di media sosial ini disusun sendiri oleh peneliti dengan model skala Likert. Skala tersebut mengungkap aspekaspek mengenai strategi presentasi diri melalui media sosial. Enam aspek dalam strategi presentasi diri tersebut sesuai dengan teori yang diungkapkan oleh Goffman yang terdiri dari Ingratiation, Intimidation, Supplification, Self-Handicapping, Self Promotion, dan Exemplification (Dayakisni dan Hudaniah, 2009). Validitas skala bergerak dari $0,308-0,637$, sedangkan uji reliabilitas item menggunakan Cronbach's Alpha adalah 0,856 .

\section{Teknik Analisa Data}

Penelitian diawali penyusunan skala Rasa Malu dan Presentasi Diri di Media Sosial oleh peneliti. Setelah selesai disusun, skala diuji coba terlebih dahulu kepada 45 orang sesuai dengan karakteristik penelitian, kemudian diuji validitas dan reliabilitasnya untuk mendapatkan item yang valid. Lalu, item valid tersebut disebar kembali kepada subjek penelitian sebanyak 110 orang. Penyebaran skala dilakukan dengan dua macam cara, yaitu melalui online dan penyebaran secara langsung. Penyebaran melalui online dilakukan dengan cara membagikan link yang berisi skala melalui Facebook dan Twitter. Penyebaran secara langsung dilakukan dengan mencari subjek sesuai dengan kriteria penelitian yang berada di wilayah sekitar peneliti berada, seperti di perumahan, sekolah, dan tempat umum lainnya. Kemudian subjek diminta untuk mengisi skala berupa booklet yang sudah dicetak.

Setelah pencarian subjek selesai dilakukan, peneliti melakukan pengelompokan hasil screening subjek. Pengelompokan tersebut bertujuan untuk memilih subjek yang sesuai dengan kriteria dan yang tidak termasuk dalam kriteria penelitian. Setelah mendapatkan 96 subjek yang sesuai dengan 
kriteria, data diinput ke dalam Ms. Excel sebagai arsip. Sedangkan pengujian skala tersebut dihitung menggunakan SPSS 2.0 dengan uji korelasi. Pearson Product Moment. Uji ini digunakan untuk mengetahui hubungan adalah rasa malu sebagai variabel bebas (variable $\mathrm{X}$ ) dan presentasi diri sebagai variabel terikat (variable Y). linier antara kedua variabel kontinu (Uyanto, 2009). Kedua variabel tersebut.

\section{HASIL DAN PEMBAHASAN}

\section{Hasil}

Penelitian dilakukan pada 96 anak remaja berusia 13 - 16 tahun yang masih aktif dalam penggunaan media sosial. Aspek yang diukur pada variabel rasa malu meliputi kognitif, afeksi, fisik, dan perilaku. Sedangkan aspek yang diungkap pada variabel presentasi diri mengungkap strategi presentasi diri yang dilakukan di media sosial meliputi ingratiation, supplification, intimidation, exemplification, selfhandicapping, dan self-promotion. Hasil penelitian yang telah dilakukan akan diuraikan serta dijelaskan sebagai berikut:

Tabel 1. Klasifikasi hasil penelitian berdasarkan usia

\begin{tabular}{ccc}
\hline Usia & $\begin{array}{c}\text { Jumlah } \\
\text { Subjek }\end{array}$ & Prosentase \\
\hline 13 tahun & 19 orang & $20 \%$ \\
14 tahun & 31 orang & $32 \%$ \\
15 tahun & 30 orang & $31 \%$ \\
16 tahun & 16 orang & $17 \%$ \\
\hline Jumlah & $\mathbf{9 6}$ orang & $\mathbf{1 0 0 \%}$
\end{tabular}

Berdasarkan tabel tersebut, terlihat jumlah subjek pada usia 14 yang paling banyak jumlahnya diantara usia lain yaitu sebanyak 31 orang atau sebesar $32 \%$. Kemudian dengan selisih jumlah yang tidak terlalu jauh adalah subjek berusia 15 tahun sebanyak 30 orang atau sebesar 31\%. Selanjutnya adalah jumlah subjek pada usia 13 tahun sebanyak 19 orang atau sebesar $20 \%$.
Kemudian yang terakhir adalah subjek pada usia 16 tahun yang berjumlah 16 orang atau sebesar 16\%. Peneliti menentukan skor tertinggi dan skor terendah pada kedua variabel dengan rumus $T$-score.

Tabel 2. Perhitungan T-score Rasa Malu

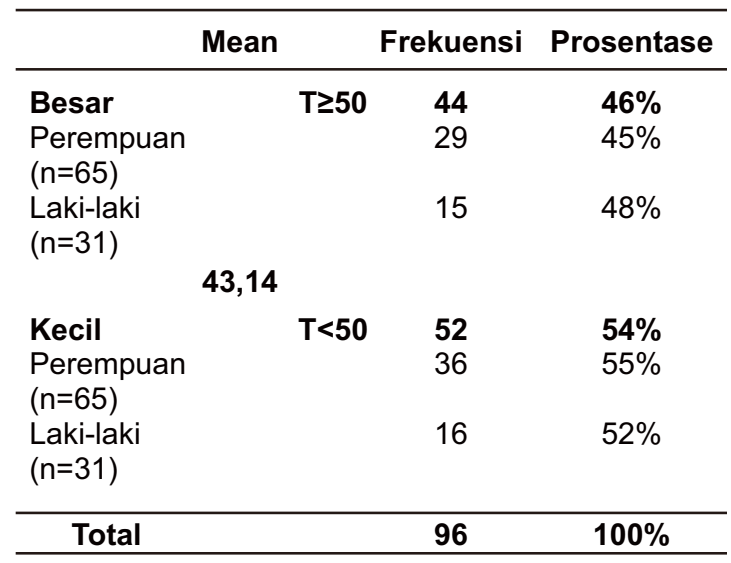

Rata - rata yang dihasilkan dari variabel rasa malu adalah 43,14. Tabel diatas menunjukkan bahwa subjek penelitian lebih banyak termasuk dalam kategori memiliki rasa malu yang kecil yaitu sejumlah 52 subjek penelitian atau sebesar 54\%. Sebaliknya subjek yang termasuk kategori rasa malu yang besar berjumlah 44 orang atau sebesar $46 \%$.

Tabel 3. Perhitungan T-score Presentasi Diri

\begin{tabular}{lccc}
\hline & Mean & Frekuensi & Prosentase \\
\hline $\begin{array}{l}\text { Tinggi } \\
\text { Perempuan } \\
(\mathrm{n}=65) \\
\begin{array}{c}\text { Laki-laki } \\
(\mathrm{n}=31)\end{array}\end{array}$ & $\mathrm{T} \geq \mathbf{5 0}$ & $\mathbf{4 2}$ & $\mathbf{4 4 \%}$ \\
& & 32 & $\mathbf{4 9 \%}$ \\
$\begin{array}{c}\text { Rendah } \\
\text { Perempuan } \\
(\mathrm{n}=65)\end{array}$ & $\mathbf{4 2 , 4 2}$ & 10 & $32 \%$ \\
$\begin{array}{c}\text { Laki-laki } \\
(\mathrm{n}=31)\end{array}$ & $\mathrm{T}<50$ & $\mathbf{5 4}$ & $\mathbf{5 6 \%}$ \\
\hline Total & & 33 & $51 \%$ \\
\hline
\end{tabular}

Berdasarkan tabel diatas dapat diketahui sebanyak 42 subjek penelitian (44\%) termasuk dalam kategori presentasi diri di 
media sosial yang tinggi. Sedangkan sebanyak 54 subjek (56\%) termasuk kategori presentasi diri di media sosial yang rendah. Sehingga subjek penelitian cenderung termasuk dalam kategori presentasi diri yang rendah di media sosial. Rata - rata yang dihasilkan dari variabel presentasi diri adalah 42,42 .

\begin{tabular}{lcccccc}
\multicolumn{5}{c}{ Tabel 4. Hasil Uji Pearson Product Moment } \\
\hline Variabel & $\begin{array}{c}\text { Std. } \\
\text { Deviation }\end{array}$ & $\mathbf{N}$ & $\mathbf{r}$ & $\mathbf{r}^{2}$ & Sig. \\
\hline Rasa Malu & 8,001 & 96 & 0,281 & $8 \%$ & 0,006 \\
$\begin{array}{c}\text { Presentasi } \\
\text { Diri }\end{array}$ & 5,133 & 96 & & & \\
\hline
\end{tabular}

Hasil analisis data dengan uji Pearson Product Moment, menunjukkan bahwa standar deviasi variabel presentasi diri adalah 5,133. Sedangkan variabel rasa malu memiliki standar deviasi sebesar 8,001. Koefisien korelasi (r) menunjukkan hasil yang positif. Hal tersebut menunjukkan bahwa ada hubungan positif antara kedua variabel yaitu rasa malu dengan presentasi diri. Nilai signifikasi yang didapatkan dari penelitian tersebut adalah 0,006 . Jika nilai signifikasi $0,006<0,05$ maka kedua variabel tersebut memiliki hubungan yang signifikan. Berdasarkan nilai koefisien $\left(\mathrm{r}^{2}\right)$, rasa malu memberikan kontribusi sebesar $8 \%$ terhadap presentasi diri di media sosial dan 92\% sisanya dipengaruhi oleh faktor lain.

\section{Pembahasan}

Berdasarkan hasil penelitian diatas, dapat diketahui bahwa terdapat hubungan yang signifikan antara variabel rasa malu dengan presentasi diri melalui media sosial. Arah hubungan yang ditunjukkan juga menunjukkan hubungan yang positif. Artinya, semakin besar rasa malu yang dimiliki remaja maka semakin tinggi presentasi diri yang dilakukan di media sosial. Begitu juga sebaliknya, semakin kecil rasa malu yang dimiliki remaja maka semakin rendah pula presentasi diri yang dilakukan di media sosial. Menurut Zarghooni (2007), presentasi diri merupakan elemen penting yang berpengaruh signifikan pada pengguna Facebook.

Ellison dkk (2007) mengungkapkan bahwa kebanyakan pengguna Facebook yakin bahwa yang akan melihat profil akun mereka adalah orang lain yang seringkali ditemui di situasi nyata. Oleh karena itu, bentuk presentasi diri tersebut tidak hanya dilakukan melalui akun Facebook namun bisa melalui akun - akun media sosial lainnya seperti Instagram, Blog, Twitter, Youtube, dan Path sesuai dengan karakteristik penelitian ini. Presentasi diri yang dilakukan di media sosial dapat berdampak pada perilaku sehari-hari dan mempengaruhi konsep diri penggunanya (Zarghooni, 2007). Konsep diri yang dimaksud dalam hal ini adalah bagaimana seseorang berpikir, mengevaluasi, serta memahami dirinya sendiri (McLeod, 2008).

Hasil penelitian menunjukkan bahwa sebanyak 68\% (65 orang) remaja berusia 13 16 tahun aktif membuka akun media sosial mereka setiap hari. Kemudian sebanyak 17\% (16 orang) persen aktif membuka akun mereka seminggu tiga kali dan sisanya sebanyak $15 \%$ (14 orang) hanya aktif seminggu sekali. Lebih lanjut diketahui bahwa remaja yang mengakses akun media sosialnya setiap hari, membutuhkan waktu rata-rata paling banyak adalah selama 15-30 menit. Pada remaja yang membuka akun media sosialnya seminggu tiga kali membutuhkan rata-rata adalah 30-60 menit. Sedangkan remaja yang mengakses akun media sosialnya seminggu sekali dengan membutuhkan waktu rata-rata 15-60 menit. Berdasarkan penelitian tersebut menunjukkan bahwa semakin jarang seseorang mengakses akun media sosialnya, maka semakin lama pula intensitas waktu yang dibutuhkan setiap kali membuka akun tersebut.

Berdasarkan hasil penelitian diatas menunjukkan bahwa pentingnya peran 
orangtua dalam mengontrol anak saat melakukan kegiatan di media sosial. Hal tersebut masih perlu diperhatikan oleh orangtua karena pada usia remaja memerlukan adanya hubungan pertemanan yang dianggap dapat dipercaya dan sejalan dengan konsep dirinya. Jika tidak ada kedekatan antara anak dan orangtua, maka orangtua tidak pernah tahu apakah kegiatan anak yang dilakukan di media sosial hanya untuk hiburan atau karena faktor lain seperti rasa malu yang dimiliki anak. Oleh karena itu, attachment (kedekatan) orangtua terhadap anak pemalu sangat penting. Dari awal kelahiran anak, orangtua memiliki pengaruh yang kuat terhadap kesejahteraan sosial dan rasa percaya diri anak yang bersifat jangka panjang (Considine, 2012). Rasa malu biasanya muncul pada usia dini yang dapat diketahui oleh orangtuanya. Orangtua berperan untuk memberikan dukungan kepada anak agar mereka memiliki keberanian saat berada di situasi sosial (Stein, 2002).

Bentuk presentasi diri yang dilakukan remaja saat melakukan kegiatan online di media sosial menunjukkan bahwa sebagian besar remaja melakukan update status dan mengunggah fotonya. Namun ternyata terdapat hasil penelitian yang menunjukkan bahwa remaja juga melakukan chatting sebagai salah satu bentuk presentasi diri. Berdasarkan hasil penelitian Rui \& Stefano (2012) orang Amerika lebih sering melakukan update profilnya melalui status di media sosial, sedangkan orang Singapura lebih sering mengunggah foto - fotonya di media sosial. Penelitian tersebut juga mengungkapkan bahwa wanita lebih banyak membagikan foto - foto yang dimilikinya namun menyeleksi terlebih dahulu foto yang dianggap kurang bagus untuk tidak diunggah.

Melalui hasil penelitian telah dijelaskan bahwa subjek penelitian menunjukkan adanya hubungan yang cenderung mengarah pada rasa malu yang kecil (54\%) dengan presentasi diri yang rendah (54\%). Hal tersebut menunjukkan bahwa tidak semua subjek penelitian yang memiliki rasa malu melakukan presentasi dirinya di media sosial. Begitu juga sebaliknya, tidak semua yang melakukan presentasi diri di media sosial adalah orang yang pemalu. Namun dengan tingkat prosentase sebesar $46 \%$, menunjukkan masih banyak subjek penelitian yang termasuk dalam kategori rasa malu yang besar. Seorang pemalu membutuhkan sebuah perantara untuk melakukan presentasi dirinya kepada orang lain. Menurut Crozier (2001) cara yang mungkin paling efektif dan terjangkau adalah kegiatan online melalui media sosial. Maka dapat terlihat dari prosentase kategori presentasi diri tinggi sejumlah $44 \%$, menunjukkan nilai hampir sepadan pada prosentase rasa malu yang besar. Kemungkinan orang pemalu melakukan interaksi yang dilakukan melalui kegiatan online adalah karena mereka dapat lebih mudah untuk mengontrol kalimatkalimat yang ingin diungkapkan daripada melakukan komunikasi secara langsung agar dapat memberikan kesan positif yang ditunjukkan pada orang lain (Crozier, 2001).

Sebanyak $45 \%$ subjek penelitian yang termasuk kategori rasa malu yang besar adalah subjek dengan jenis kelamin perempuan, sedangkan sebanyak $48 \%$ adalah subjek dengan jenis kelamin laki-laki. Walaupun hasil prosentase laki-laki lebih besar, keduanya tidak memiliki perbedaan yang signifikan. Hal tersebut sesuai dengan hasil penelitian dari Civitci (2010) yang mengungkapkan bahwa jenis kelamin tidak menunjukkan perbedaan yang signifikan dalam menentukan tingkat rasa malu. Lebih lanjut dijelaskan bahwa rasa malu disebabkan karena tingkatan sosial yang dimiliki oleh remaja. Remaja pada tingkat sosial rendah lebih malu daripada remaja pada tingkat sosial menengah maupun yang lebih tinggi. Rasa 
malu merupakan sifat yang dipengaruhi oleh gen atau keturunan (Stein, 2002). Menurut Crozier (2001) terdapat beberapa faktor penyebab seseorang menjadi malu, antara lain: (a) memiliki cacat fisik; (b) bermasalah dengan aksen atau cara bicaranya; (c) mendapat kekerasan saat anak-anak; (d) dibesarkan oleh orangtua yang terlalu cemas; (e) trauma; (f) saat usia muda berada di tempat penampungan anak; dan (g) situasi yang membuat malu.

Namun jika dilihat dari prosentase presentasi diri yang dilakukan di media sosial, pada subjek perempuan menunjukkan prosentase yang lebih tinggi (49\%) daripada laki-laki (32\%). Sesuai dengan penelitian yang dilakukan de Graaf (2011), mengungkapkan bahwa perempuan lebih banyak memiliki foto dan pesan kecil pada profilnya daripada laki-laki. Selain itu perempuan juga lebih banyak melakukan update status. Berdasarkan penelitian, lakilaki lebih banyak melakukan presentasi diri di media sosial dengan melakukan video sharing seperti Youtube (Lenhart dkk, 2007). De Graaf (2011) mengasumsikan bahwa perempuan yang lebih terbuka dengan memberikan banyak informasi di media sosial (foto, status, pesan) daripada laki-laki, dapat dikatakan bahwa perempuan lebih aktif dalam membentuk identitasnya.

Nilai koefisien sebesar $8 \% \quad\left(r^{2}\right)$ menunjukkan bahwa rasa malu memberikan kontribusi sebesar $8 \%$ terhadap presentasi diri remaja di media sosial. Sebanyak $92 \%$ sisanya dapat dipengaruhi faktor lain. Faktor lain yang dapat mempengaruhi seseorang melakukan presentasi diri di media sosial antara lain narsisme, kecemasan sosial, kesepian (loneliness), dan harga diri (Arianna, 2014). Di sisi lain, rasa malu pada beberapa budaya di Indonesia bisa dikatakan sebagai nilai (value) yang harus dimiliki setiap individu dalam melakukan interaksi dengan orang lain. Seperti contoh dalam budaya Jawa dikenal dengan istilah sungkan yaitu dimana seseorang merasa tidak enak hati saat berada di situasi tertentu, contohnya pada saat bertemu dengan orang yang lebih tua. Selain itu berdasarkan hasil penelitian menunjukkan bahwa tidak semua pengguna media sosial yang melakukan presentasi diri adalah seorang pemalu. Begitu juga sebaliknya, tidak semua pemalu akan melakukan presentasi diri dimedia sosial.

\section{SIMPULAN}

Hasil penelitian yang telah dilakukan menunjukkan bahwa terdapat hubungan antara rasa malu dengan presentasi diri remaja melalui media sosial. Terlihat hubungan positif antara kedua variabel dengan besar koefisien korelasi (r) 0,281. Selain itu kedua variabel juga memiliki hubungan signifikan dengan nilai signifikasinya 0,006 . Maka dapat disimpulkan bahwa hipotesis penelitian ini diterima. Namun rasa malu hanya memberikan kontribusi sebesar $8 \%$ pada presentasi diri remaja melalui media sosial. $92 \%$ sisanya dapat dipengaruhi faktor lain seperti narsisme, kecemasan sosial, kesepian, dan harga diri.

Implikasi dari penelitian ini diperuntukkan bagi para orangtua yang memiliki anak dengan rasa malu besar perlu memberikan dukungan serta mengajari mereka agar merasa nyaman saat berada di situasi sosial. Pertolongan dari profesional tidak mampu membantu mereka menghadapi rasa malu yang dimilikinya, karena faktor kedekatan dari orangtua sangat berpengaruh. Saat anak telah menginjak usia remaja, orangtua perlu melakukan peran ganda untuk menjadi teman sebayanya agar anak dapat terbuka dalam menceritakan permasalahan yang dihadapi. Kemungkinan hal tersebut akan mengurangi intensitas anak dalam melakukan kegiatan online, yang juga dapat menyebabkan kecanduan. 
Bagi peneliti selanjutnya dapat meneliti faktor lain yang memiliki hubungan dengan presentasi diri di media sosial. Selain itu peneliti selanjutnya juga dapat memfokuskan salah satu media sosial saja untuk diteliti, karena setiap media sosial memiliki karakteristik yang berbeda sehingga memiliki kekurangan dan kelebihan masing-masing.
Namun coba hindari penelitian pada pengguna media sosial Facebook karena sudah banyak penelitian yang menggunakan media sosial tersebut. Peneliti selanjutnya juga dapat meneliti tingkat rasa malu seseorang jika ditinjau dari budaya yang dimiliki.

\section{References}

Albarran, A. B. (2013). The social media industries. New York: Routledge

Aliana, S. S. (2015). Wanita ini babak belur dipukuli teman kencan online. Diakses tanggal 07 Februari 2015 diperoleh dari http://teknologi.news.viva.co.id/news/read 1586439-wanita-ini-babak-belur-dipukuliteman-kencan-online

Arianna, P. F. (2014). Online self-presentation: examining the relationship between facebook use, narcissism, social anxiety, loneliness and self-esteem. A thesis submitted to the Department of Psychology at Glasgow Caledonian University in the candidacy for the master degree of science

Arroyo, A., Nevarez, N., Segrin, C., \& Harwood, J. (2012). The association between parent and adult child shyness, social skills, and perceived family communication. Journal of Family Communication, 12, 249 - 264

Azwar, S. (2014). Reliabilitas dan validitas: edisi $I V$. Yogyakarta: Pustaka Pelajar (2001). Metode penelitian. Yogyakarta: Pustaka Pelajar

Baker, L. R., \& Oswald, D. L. (2010). Shyness and online social networking services. Journal of Social and Personal Relationship, 27 (7), $1-22$

Broto, G. S. D. (2014). Siaran pers tentang riset kominfo dan UNICEF mengenai perilaku anak dan remaja dalam menggunakan internet. Diakses tanggal 1 Juni 2014 diperoleh dari http://kominfo.go.id/ index.php/content/detail/3834/Siaran+Per
$s+N o .+17-P I H-K O M I N F O-2-$ $2014+$ tentang + Riset + Kominfo + dan $+U N I$ $C E F+$ Mengenai + Perilaku + Anak + dan $+R$ emaja + Dalam + Menggunakan+Internet + / 0/siaran_pers\#.U43KYnYQdKh

Carducci, B. J., \& Golant, S. (2009). Shyness: understanding, hope, and healing. New York: Harper Collins

Civitci, N. (2010). Social comparison and shyness in adolescents. Egitim ArastirmalariEurasian Journal of Educational Research, 38, 90-107

Considine, M. E. (2012). Shyness: causes and impact. (Online). Diakses tanggal 25 Januari 2015 diperoleh dari http://www.netce.com/coursecontent.php? courseid $=799$

Crozier, W. R. (2001). Understanding shyness; psychological perpectives. Portland: Ringgold Inc

Dayakisni, T., \& Hudaniah. (2009). Psikologi sosial. Malang: UMM Press

DeLamater, J. D., \& Myers, D. J. (2007). Social psychology: sixth edition. Belmonth: Thomson Wadsworth.

DeGraaf, M. M. A. (2011). The relationship between adolescent's personality characteristics and online self presentation. (Online). Diakses tanggal 15 Februari 2015 diperoleh dari http://essay.utwente.nl/60892/1/Graaf_de, _Maartje_s_0188808_scriptie.pdf

Dingman, R. L., \& Bloom, J. W. (2012). Managing shyness. Indiananpolis: Dog Ear 
Ellison, N B., Steinfield C., \& Lampe, C. (2007). The Benefits of Facebook "Friends": Social Capital and College Students Use of Online Social Network Sites. Journal of Computer-Mediated Communication, 12, $1143-1168$

Fahmi, A. B. (2011). Mencerna situs jejaring sosial. Jakarta: Elex Media Komputindo.

Gibbs, J. L., Ellison, N. B., \& Heino, R. D. (2006). Self Presentation in Online Personals. Communication Research, 33 (2), 152 177

Grietens, H. (1999). Attitudes towards social limits, undersocialized behavior and selfpresentation in young people. Belgia: Leuven University Press

Hurlock, E. B. (1997). Psikologi perkembangan: suatu pendekatan sepanjang rentang kehidupan. Jakarta: Erlangga.

. (1980). Psikologi perkembangan: suatu pendekatan sepanjang rentang kehidupan edisi kelima. (Terj. Istiwidayanti \& Soedjarwo). Jakarta: Erlangga.

Jansen, A., Konig, C. J., \& Melchers, K. G. (2010). The interactive effect of impression motivation and cognitive schema on selfpresentation in a personal inventory. Journal of Applied Social Psychology

Latipun. (2011). Psikologi eksperimen: edisi kedua. Malang: UMM Press

Lenhart, A., Madden, M., Smith, A., \& Macgill, A. (2007). Teens and Social Media. Diakses tanggal 04 Februari 2015 diperoleh dari http://www.pewinternet.org/2007/12/19/te ens-and-social-medial

Lewis, M. A., \& Neighbors, C. (2005). Self determination and the use of self presentation strategies. Journal of Social Psychology, 145 (4), 469-489

Maltby, J., Day, L., \& Macaskill, A. (2007). Personality, individual defferences, and intelligence. Harlow: Pearson.McLeod, S. (2008). Self concept. Diakses tanggal 25 Januari 2015 diperoleh dari http://www.simplypsychology.org/self- concept.html

Nurudin. (2012). Tuhan baru masyarakat cyber di era digital. Malang: Aditya Media Publishing

Ningrum, D. W. (2014). Demi selfie cantik, triana operasi plastik ratusan juta rupiah. Diakses tanggal 07 Februari 2015 diperoleh dari http://tekno.liputan6.com/read/2042789/d emi-selfie-cantik-triana-operasi-plastikratusan-juta-rupiah

O'Keeffe, G. S., \& Pearson, K. C. (2011). Clinical report: the impact of social media on children, adolescents, and families. Journal of the American Academy of Pediatrics, 127 (4), $800-804$

Papalia, D. E., Olds, S. W., \& Feldman, R. D. (2009). Human development: perkembangan manusia, edisi 10. Jakarta: Salemba Humanika.

Rovai, A. P., Baker, J. D., \& Ponton, M. K. (2013). Social science research design and statistics: second edition. Virginia: Watertree Press

Rui, J., \& Stefano, M. A. (2012). Strategic selfpresentation online: a cross-cultural study. Computers in Human Behavior, 29, $110-$ 118

Santrock, J. W. (2003). Adolescence perkembangan remaja. Jakarta: Erlangga.

Sarwono, S. W., \& Meinarno, E. A. (2012). Psikologi sosial. Jakarta: Salemba Humanika

Stein, M. B. (2002). Triumph over shyness: conquering shyness and social anxiety. New York: McGraw-Hill

Schlenker, B. R., \& Leary, M. R. (1982). Social anxiety and self presentation: a conseptualization and model. Psychological Bulletin, 92 (3), 641-669.

Uyanto, S. S. (2009). Pedoman analisis data dengan SPSS: edisi 3. Yogyakarta: Graha Ilmu

Wong, W. K. W. (2012). Faces on facebook: a study of self presentation and social support on facebook. SS Student E-Journal, 1, 184214 
Herdyani Kusumasari \& Diana Savitri Hidayati: “Rasa Malu dan Presentasi Diri Remaja”...(91 - 105)

Zarghooni, S. (2007). A study of self-presentation in light offacebook. Paper was published on Institute of Psychology, University of Oslo
Zuriah, N. (2009). Metodologi penelitian sosial dan pendidikan: teori-aplikasi. Jakarta: Bumi Aksara 